\title{
A Review of Literature: Plagiarism in the Papers of Turkish Context
}

\author{
Tuba Gokmenoglu ${ }^{1}$ \\ ${ }^{1}$ Faculty of Education, European University of Lefke, Lefke, Turkish Republic of Northern Cyprus \\ Correspondance: Tuba Gokmenoglu, Faculty of Education, European University of Lefke, Lefke, 99800, Turkish \\ Republic of Northern Cyprus. Tel: 90-392-660-2000. E-mail: tgokmenoglu@eul.edu.tr
}

Received: July 29, 2017

doi:10.5539/hes.v7n3p161
Accepted: August 9, 2017

Online Published: August 22, 2017

URL: http://doi.org/10.5539/hes.v7n3p161

\begin{abstract}
The present review attempted to address the direction of plagiarism literature in Turkish context. 15 studies conducted in Turkey on plagiarism were analyzed through content analysis. The context, purposes, methodological issues and results of researching plagiarism were categorized. The findings of this review indicated that although plagiarism's raising legal and ethical concerns is acknowledged by Turkish researchers, there are limited numbers of studies exploring the plagiarism perceptions, views, situations and reasons of Turkish graduate students and professors.
\end{abstract}

Keywords: plagiarism, higher education, academy, dishonesty

\section{Introduction}

Everything has been started with my roommate's plagiarized statistics course project in 2010. The event happened in a doctoral course at a very prestigious university in Turkey. Another research assistant stole her project, wrote his name on it, and submitted to instructor. I remember how my roommate was disappointed by this event. After all, she proved that the project had been prepared in her computer and finally the thief was failed from the course. Not always the trends and needs make researchers to carry out a study, but sometimes the events and experiences make researchers to conduct a research. After this event, we searched for the plagiarism concepts of research and teaching assistants in the same high raking university immediately, and found that although the research assistants had negative stance towards academic dishonesty, they also unanimously rationalized the act of plagiarism by problems with using foreign language, time constraints, lack of knowledge about plagiarism, overloaded course requirements, lack of ideas, lack of interest in the topic, difficulty of the assignment, lack of understanding of the assignment (Eret \& Gokmenoglu, 2010). Years later, in 2015, one day I was surfing on the Google Scholar, I met a paper about my advisee's topic. However, it had the same tittle with my student's thesis tittle. Could it be such a coincidence since her thesis is based on the historical children plays of Turkish Cypriots? It was a very special and culture-based topic. When I simply clicked on the link, I realized that this time, I was the victim of a thief. The co-advisor of the thesis made a paper without any permission of me. She used all the sentences as same with the only exception of using "game" rather than "play" as we preferred in the thesis. This was very dramatic dejavu for me and got a gift of heavy headache lasted almost a week. I went to a web page of higher education council of Northern Cyprus, nothing found about the issue. I talked with an advocate, and he told me that " $\mathrm{Dr}$, it is not surprising event, it is very common, it is just a family custom in our academy; we will not reach the destination that you want to reach at the end of the case". And yes, I could nothing legally yet except for the conducting and following new research on plagiarism.

Among this seven-year period, our first study got more than 45 citations from other nations' researchers which means the number of papers searching on the reasons and the effects of plagiarism, plagiarism in different age and grade groups is increasing day by day all over the world. In the literature, almost all studies started with the definition of the plagiarism which is literally accepted as an intellectual theft, cheating or academic dishonesty: to use or represents another person's ideas in your writing without acknowledging or referencing the author (Gibaldi, 1999); the theft of words and ideas of others (Park, 2003); academic misconduct (Stern \& Havlicek, 1986, p. 129); thieving thoughts (Whiteneck, 2002); textual misappropriations (Thomas, 2000, p. 277); and forgery (Groom, 2000). Furthermore, Janowski (2002) gives a list of operational definitions of the plagiarism;

- $\quad$ "Buying or downloading a paper from a research service or a term-paper mill and offering it as your own. 
- Turning in another student's work, with or without that student's knowledge, as your own.

- Copying any portion of another's work without proper acknowledgment.

- Copying material from a source and supplying proper documentation, but leaving out quotations marks or failing to indent properly.

- Paraphrasing ideas and language from a source without proper documentation (p. 26)."

If the word "plagiarism" searched on the Google, millions of pages to be found, this may show how it is a hot topic today. It is obvious that the issue was also very popular in history. Park (2003) states that "copying from other writers is probably as old as writing itself" (p. 473). The history of plagiarism goes back to ancient Romes; they had used the word "plagiarius" in the sense of kidnapper, seducer, plunderer, and from the word "plagium" had been used as kidnapping, and from "plaga" snare, net, from "p(e)lag"; flat, spread out 5.500 years ago (Plagiarism, n. d.).

As it can be inferred from the Janowski's (2002) list of definitions, the concept of plagiarism differs from the cheating as regards the intention of acting; plagiarism can be happened both deliberately and inadvertently opposing to the cheating which is a deliberate action (Devlin \& Gray, 2007). This deliberate or inadvertent action is appeared among different education level of students which are at kindergarten (Olson \& Shaw, 2011; Yang, Shaw, Garduno, \& Olson, 2014); secondary school students (Kam, Hue, \& Cheung, 2017); undergraduate students (Arhin \& Jones, 2009; Ashworth, Bannister, \& Thorne, 1997; Gullifer \& Tyson, 2014; Scanlon \& Neumann, 2002), and graduate students (Baty, 2001; Love \& Simmons, 1998; Morgan \& Thomson, 1997). Years ago, Paldy (1996) argues this and points as "won't go away" (p. 1). It has been almost 21 years since Paldy argued and it has not gone away yet. Rather, it is growing day by day and problem consists of many types of acts. Well-known originality checking service Turnitin (2015) conducted a survey with 879 higher and secondary educators around the world to explore and measure the common and problematic plagiarism events among their students. Therefore, "The Plagiarism Spectrum" suggests 10 categories of plagiarism named Clone, CTRL-C, Find-Replace, Remix, Recycle, Hybrid, Mashup, 404 Error, Aggregator, Re-tweet. Among all these categories, the most frequently observed instances fall in the categories of Clone (9.5 out of 10), Mashup (9.1), and CTRL-C (8.9). These most problematic tags of Turnitin; Clone refers to a submission of other's work, steal word by word; Mashup means using a mix of more than one material without proper citation; and CTRL-C refers to taking significant portion of a work without any change and citation (Turnitin, 2017).

As Turnitin refers, many evidences show that the problem of plagiarism is expending in scope and increasing in number of cases (Papermasters, 2009; Price, J. \& Price, R., 2005). Broeckelman and Pollock (2006) carried out a project on the attitudes of students and instructors toward academic dishonesty at Ohio University, and the results show that $84.1 \%$ of the undergraduate students, and $55.2 \%$ of the graduate students admitted to behave against academic honesty rules with several types of behaviors, and various degrees of seriousness during the year 2005. Another study investigated the unethical behaviors among undergraduate and graduate students, showed that problem of plagiarism did not show variation with respect to the education level (Sheard, Markham, \& Dick, 2003). Gullifer and Tyson's (2014) study concluded that only half of the 3405 students in an Australian university had read the plagiarism policy and had confusion apparent about which behavior counted as plagiarism. In their study of faculty members' view on student plagiarism, Bruton and Childers (2016) found that if the student violated the plagiarism rules unintentionally faculty members did not penalize the student that did not coincide with the ones written in the syllabi about the penalty of plagiarism.

Although plagiarism often results in severe punishment in academic environment as failure from the course or dismissing from the school (Gibaldi, 1999), the extensive number of writers alert that the plagiarism is clearly a growing problem which is on the rise in universities in recent times (Bowden, 1996; Paldy, 1996; Park, 2003; Verco \& Wise, 2006; Wilhoit, 1994; Wood, 2004). Why this crime committed by many people from kindergarten to graduate schools is also studied by scholars. Studies found multiple reasons of plagiarism; for instance, the qualitative research by Love and Simmons (1998) which was designed in part to determine the factors that affect the graduate students' behavior in a college of education associated with cheating and plagiarism, showed that there are two types of the internal and external factors which are contribute to, and inhibit behaviors. While the internal inhibiting factors were self-confidence, positive professional ethics, fairness to authors and to others, fear, and guilt; the external inhibiting factors were probability of being caught and need for knowledge in the future. On the other hand, the internal contributing factors were negative personal attitudes and lack of proficiency, whereas the external contributing factors are grade, time, and task difficulty. In addition, the qualitative study done by Devlin and Gray (2007) indicated that the possible reasons of the act of plagiarism in 56 Australian universities are a wide and "institutional admission criteria; student understanding of plagiarism; 
poor academic skills; a range of teaching and learning factors; personality factors and external pressures" (p. 181). The inhibiting factors may show difference with respect to grade level. Although graduate students had other rationales to get admission or success, or being published in second-language, the studies with undergraduate students showed lack of understanding the concept of plagiarism, and the consequences of it (Ehrich, Howard, Mu, \& Bokosmaty, 2016). Furthermore, time constraints and overloaded courses were also other inhibiting factors leading students to plagiarize. Gururajan and Roberts (2005) conducted a study to explore the students' attitudes toward this ethical and moral matter, and found that both tutors and students have unanimous attitudes towards the justification of plagiarism by workload.

Although there is a growing body of literature focus on the student plagiarism in terms of its definitions, prevalence, what lead the students to plagiarize, and the consequences, "students have no monopoly on plagiarism as a form of dishonest behaviour" (Park, 2010, p. 473). Even teachers, instructors, and authors of research often plagiarize. Many studies showed that supervisors or other academic staff had also plagiarized (Bruten \& Childers, 2016; Martin, 1986; Witton, 1973). This is a dangerous and severe problem of academy since this staff is expected to teach what the plagiarism is to students.

The most comprehensive project was conducted by the team of Education Policy Research and Application Centre of Istanbul's Bogazici University by examining 470 master's theses and 130 doctoral dissertations published between 2007 and 2016 in Turkey. The project group announced that there were "heavy plagiarism" in $34 \%$ of the theses; the rate of the plagiarism in the theses of private universities was $46 \%$ whereas the rate of plagiarism 31\% in public universities (Hurriyet Daily News, 2016). The findings of the project were called as scandal by journalists. This is not new news about the act of plagiarism of our academicians. This of Turkish authors has been also discussed by researchers of other nations in the area of nursing and medical. To illustrate, in her study Amos (2014) found that Turkey was one of the topped countries with the rate of $61.5 \%$ plagiarism in biomedical literature published in PubMed between 2008 and 2012. While the situation is so severe with these figures, how much do the researchers devote time and energy to explore the students and academic staff's concepts, rationales and consequences of the acts of plagiarism in Turkey? Within this context, the purpose of this study is to review the most current published literature on the topic of plagiarism in Turkish context.

\section{Method}

\subsection{Research Design}

The present study was designed as a review study aiming to "synthesize research findings to determine the true state of knowledge in relation to the phenomena in question" (Krathwohl, 1998, p. 553). Within this frame, the objective of the present review is to draw a clear interpretation of the research for policy makers and researchers who are interested in the topic of plagiarism. More closely, this review analyzes the contents and findings of the earlier studies conducted on plagiarism between 2007 and 2017 in the area of social sciences. The study included not only the manuscripts of indexed journals but also the master's theses and doctoral dissertations published between the given ranges.

\subsection{Data Collection and Analysis Procedures}

The following databases were searched for the relevant articles; Australian Education Index, British Education Index, ERIC, EBSCO, DOAJ, Index Copernicus, SCOPUS, Social Sciences Citation Index, Google Scholar, and TUBITAK ULAKBIM. To find appropriate research, the following keywords used in the search; plagiarism in Turkey, research ethics in Turkey, unethical research, and academic dishonesty. In case of articles were written in Turkish, the search were handled both in Turkish and English languages. By using university reference librarian link, the full texts of each article were downloaded. There were 45 articles on plagiarism published in Turkey between 2007 and 2017. The articles out of the field of social sciences were eliminated. In total 32 articles were found written on the plagiarism by the authors of Turkish universities. However, 18 of them were excluded from the sample since they did not include any research processes. They were mostly opinion papers on the concept of plagiarism, and some of them were explaining what they experienced with the law process as a victim. Therefore, total of 14 articles were included in the study. For the theses and dissertations, Higher Education Council theses database was visited and three master's theses and one doctoral dissertation were met. Among these, to prevent the duplication in the sample, the doctoral dissertation and one of the master's theses were also excluded from the sample since they were published as an article, too. One master's thesis conducted in 2008 was also eliminated since there was not digital publishing permit to Higher Education Council's database by its author. To sum up, in total of 14 articles and one master's thesis comprised of the sample of the study. 
In this study, the qualitative data collected through documents were subjected to both descriptive and content analyses to explore the research purposes including both contents and contexts, and the results of the studies in the sample. First of all, all the studies were descriptive categorized in terms of their content, publication year, and sample. Then the patterns of the purposes and results of the studies were explored and categorized.

\section{Findings}

To review the recent studies in Turkish context, 10 databases were searched and found 14 articles and one master's thesis in the social sciences. According to the Table 1, four of the studies were published in 2014, and rest of them distributed fairly according to years. Whereas there were two experimental design researches; most of the studies carried out as a survey study. The number of qualitative studies is three, and there was only one mixed design research. When the samples of the studies were examined, it was found that most of the research were done with university students. The research downloaded from the databases were classified with respect to publication year, content, design, sample and findings, and presented in Table 1. The research was presented in a time order from the most recent to the least.

Table 1. Database of research published between 2007 and 2017 on plagiarism in social sciences

\begin{tabular}{|c|c|c|c|c|c|}
\hline Research & Year & Content & Design & Sample & Findings \\
\hline Article 1 & 2017 & $\begin{array}{l}\text { Elimination of } \\
\text { misconceptions on } \\
\text { plagiarism }\end{array}$ & $\begin{array}{l}\text { Experimental } \\
\text { design } \\
\text { Survey }\end{array}$ & $\begin{array}{l}\text { Secondary school } \\
\text { students }\end{array}$ & Fail to reject hypothesis \\
\hline Article 2 & 2017 & Views on plagiarism & $\begin{array}{l}\text { Quantitative } \\
\text { Survey }\end{array}$ & $\begin{array}{l}\text { Turkish and American } \\
\text { university students }\end{array}$ & Cultural differences found \\
\hline Article 3 & 2016 & Views on plagiarism & $\begin{array}{l}\text { Quantitative } \\
\text { Survey }\end{array}$ & Graduate students & Found knowledgeable \\
\hline Article 4 & 2015 & Views on plagiarism & $\begin{array}{l}\text { Quantitative } \\
\text { Survey }\end{array}$ & $\begin{array}{l}\text { Turkish and German } \\
\text { university students }\end{array}$ & Cultural differences found \\
\hline Article 5 & 2014 & $\begin{array}{l}\text { Tendencies and reasons of } \\
\text { Internet plagiarism }\end{array}$ & $\begin{array}{l}\text { Quantitative } \\
\text { Survey }\end{array}$ & University students & $\begin{array}{l}\text { Gender, department and length of } \\
\text { computer use were found to be } \\
\text { significant factors }\end{array}$ \\
\hline Article 6 & 2014 & $\begin{array}{l}\text { Views on Internet plagiarism } \\
\text { experiences }\end{array}$ & $\begin{array}{l}\text { Qualitative } \\
\text { Interview } \\
\text { Focus group } \\
\text { interview }\end{array}$ & University students & $\begin{array}{l}\text { Reasons of plagiarism explored; } \\
\text { personal characteristics, peer relations, } \\
\text { role of instructors, use of technology, } \\
\text { the weight of course }\end{array}$ \\
\hline Article 7 & 2014 & $\begin{array}{l}\text { Tendencies to make } \\
\text { plagiarism }\end{array}$ & $\begin{array}{l}\text { Quantitative } \\
\text { Survey }\end{array}$ & University students & $\begin{array}{l}\text { Gender, age, department they studied, } \\
\text { year of study and SES level were } \\
\text { found to be significant factors }\end{array}$ \\
\hline Thesis 1 & 2014 & $\begin{array}{l}\text { Reasons of internet } \\
\text { plagiarism }\end{array}$ & Mixed & $\begin{array}{l}\text { Secondary school } \\
\text { students }\end{array}$ & $\begin{array}{l}\text { Reasons of plagiarism; heavy course } \\
\text { load, too much homework and } \\
\text { clearance of homework }\end{array}$ \\
\hline Article 8 & 2013 & $\begin{array}{l}\text { Knowledge and types of } \\
\text { plagiarism }\end{array}$ & $\begin{array}{l}\text { Quantitative } \\
\text { Survey }\end{array}$ & University students & $\begin{array}{l}\text { Insufficient knowledge, Internet } \\
\text { plagiarism is the most common }\end{array}$ \\
\hline Article 9 & 2011 & Reducing plagiarism & $\begin{array}{l}\text { Experimental } \\
\text { design } \\
\text { Survey }\end{array}$ & University students & $\begin{array}{l}\text { Turnitin is effective in reducing } \\
\text { plagiarism }\end{array}$ \\
\hline Article 10 & 2011 & $\begin{array}{l}\text { Views on instructor role in } \\
\text { Internet plagiarism }\end{array}$ & $\begin{array}{l}\text { Quantitative } \\
\text { Survey }\end{array}$ & University students & $\begin{array}{l}\text { Instructor s' reading and checking the } \\
\text { contents of the homework, giving } \\
\text { information about what the plagiarism } \\
\text { is, explaining the consequences of } \\
\text { plagiarism affect the tendency of }\end{array}$ \\
\hline
\end{tabular}




\begin{tabular}{|c|c|c|c|c|c|}
\hline & & & & & plagiarism \\
\hline Article 11 & 2010 & $\begin{array}{l}\text { Knowledge, views on } \\
\text { plagiarism and reasons }\end{array}$ & $\begin{array}{l}\text { Quantitative } \\
\text { Survey }\end{array}$ & Graduate students & $\begin{array}{l}\text { Graduate students had negative } \\
\text { attitudes. Reasons; publishing in } \\
\text { second language, time constraints, lack } \\
\text { of comprehensive knowledge on } \\
\text { plagiarism }\end{array}$ \\
\hline Article 12 & 2009 & $\begin{array}{l}\text { Reasons and solutions of } \\
\text { plagiarism }\end{array}$ & $\begin{array}{l}\text { Qualitative } \\
\text { Interview }\end{array}$ & $\begin{array}{l}\text { University_-secondary } \\
\text { school students }\end{array}$ & $\begin{array}{l}\text { Lack of awareness about plagiarism, } \\
\text { lack of knowledge about writing } \\
\text { research papers, lack of motivation to } \\
\text { do research, lack of freedom to express } \\
\text { their own opinions or voices, negative } \\
\text { attitude towards writing }\end{array}$ \\
\hline Article 13 & 2009 & $\begin{array}{l}\text { Develop a scale on } \\
\text { plagiarism tendency }\end{array}$ & $\begin{array}{l}\text { Quantitative } \\
\text { Survey }\end{array}$ & University students & $\begin{array}{l}22 \text { item-scale was developed with } 4 \\
\text { subscales }\end{array}$ \\
\hline Article 14 & 2007 & $\begin{array}{l}\text { Reasons and solutions of } \\
\text { plagiarism }\end{array}$ & $\begin{array}{l}\text { Qualitative } \\
\text { Document }\end{array}$ & University students & $\begin{array}{l}\text { The reasons; limited time, course } \\
\text { requirements. Solutions; } \\
\text { thought-provoking homework, enough } \\
\text { time to submit homework }\end{array}$ \\
\hline
\end{tabular}

Based on the document analysis results, there were three main categories describing the rationales of the current research which are "views on plagiarism", "tendency and knowledge of plagiarism" and "reasons and solutions".

The studies in the first category of "views on plagiarism" aimed to figure out what students think about the plagiarism, and they mostly found that they have negative attitudes towards plagiarism. Eret and Gokmenoglu (2010) found that graduate students in a high ranking university have negative attitudes towards plagiarism, but they did not have a comprehensive knowledge on it. However, a more recent study of Kocak and Ozbek's (2016) concluded that more $90 \%$ of the master's and doctorate students in the sample found the given cases of plagiarism unethical such as "Citing without providing a reference", "Publishing an article by translating it without the permission of its author", "Using someone else's quantification approach without permission", and "Publishing someone else's research with own name". The study conducted with 193 undergraduate students of Hacettepe University and 107 undergraduate students of University of North Carolina at Chapel Hill to explore their views on plagiarism resulted in cultural differences. According to findings, students of University of North Carolina at Chapel Hill already knew what the plagiarism was before being admitted to the university and had fewer tendencies towards showing the act of plagiarism (Ozenc Ucak \& Unal, 2017). Another cross-cultural study was carried out with German and Turkish university students to figure out their perception of plagiarism. Findings indicated that German students had a higher sensitivity to plagiarism and were better in identifying it (Kayaoglu, Erbay, Flitner, \& Saltas, 2015). Studies showed that if the students had insufficient knowledge on plagiarism, they had more tendencies to plagiarism. Avarogullari and Ata (2013) pointed that almost half of the students in Mugla Sitki Kocaman University heard the issue for the first time. The tendencies of students changed with respect some characteristics. According to these recent studies, gender, department, year of the education, and socio-economic status level were the significant factors affecting the tendencies of university students (Eret \& Ok, 2014; Gumusgul, Ustun, Isik, \& Demirel, 2014). Both two studies found that males had higher tendency to plagiarism. Moreover, teacher candidates of computer education and instructional technology department showed more tendency to internet plagiarism compared with other departments of faculties of education.

Finally, the reasons of plagiarism were explored by four studies. Eret and Ok (2014) conducted a survey study and found that the factors affecting university students' tendency to were time constraints, heavy workload, and difficulty of the assignments/projects. Similarly, Ersoy (2014) also studied on the reason of plagiarism, and interviewed with the students who reported as made plagiarism. The findings showed that personal characteristics, peer relations, role of instructors, use of technology, and the weight of course were the rationale behind their plagiarism acts. Secondary school students also made plagiarism since there were heavy course load, too much homework and clearance of homework (Uzun, 2014). Furthermore, Ersoy and Ozden (2011) found that if the instructors give information about the plagiarism, read and check the contents of homework in detail, and explain the consequences of plagiarism, the tendency of university students to plagiarism decreases. Different 
from these findings, Eret and Gokmenoglu (2010) mentioned the being have to publish in a foreign language was another factor of plagiarism among graduate students. Moreover, Rocha Erkaya (2009) also ordered the reasons of plagiarism among high school and university students as their lack of awareness about plagiarism, lack of knowledge about writing research papers, lack of motivation to do research, lack of freedom to express their own opinions or voices, and negative attitude towards writing.

\section{Discussion and Conclusion}

Plagiarism by students is a moral concern since it generates important ethical and moral matters about intended and existing behaviors, and applications (Park, 2003). Although the literature of this concern has been growing day by day, according to the findings of this study, plagiarism was studied rarely by the authors who worked in Turkish contexts. There were 15 researches meeting the criteria of this study. Most of the samples composed of university and high school students. Nearly all the studies reported the views and knowledge level of students on plagiarism. There are vast amount of self-report studies in the literature (Rakovski \& Levy, 2007). These studies measure to what extend students do plagiarism, and why due to their own reports. As parallel with the trend in literature, almost all the studies in the sample are self-report plagiarism research. For instance, Ersoy (2014) worked on the individuals' self-reporting plagiarism experiences with focus group interviews. However, this strategy has been also criticized by scholars owing to the fact that this design heavily based on the honesty of the participants who showed dishonest behavior (Newstead, Franklyn-Stokes, \& Armistead, 1996); "Self-reporting of any behaviour is problematic; self-reporting of dishonest behaviour is even more challenging" (Scanlon \& Neumann, 2002, p. 378) causing the severe validity and the credibility of the self-reporting problems for survey studies, too. According to Walker (2010) the rationale behind this validity problem is the lack of standardization of surveys using to detect perceptions of participants on plagiarism. In this context, the standardization was also not met by Turkish authors in the sample except for the one research by Eminoglu and Nartgun (2009) which was a scale development study itself. To prevent from the validation problem of self-reporting studies, the research needs to be designed a mixed methodology studies and triangulated for validation by the document analysis to detect participants' plagiarism acts on their recent documents (Denzin, 2012).

Literature says that this dire problem has arisen from the widespread internet usage with the age of technology (Paynter \& Mills, 2004; Sisti, 2007). Parallel with this, the studies in the sample also focus on the effect of Internet usage on the plagiarism act of students. The studies also showed that Internet make their plagiarism act is easier. Moreover, students in these studies claimed that they were not aware of taking sentences from Internet was an act of dishonesty (Eret \& Ok, 2014).

The literature of plagiarism is also interested in detecting infringement among certain groups, the reasons for committing plagiarism and the prevention strategies. Similar with the literature, the studies in the present sample dealt with the same issues of plagiarism. All the results of these studies need to be considered seriously by faculty members and teachers. If they propose students mind busting project topics to be submitted in an acceptable time period, arrange the courses' workloads by cooperating with other courses' instructors, give clear definition of the plagiarism in the syllabi, teach how to detect, check and prevent plagiarism, and inform students obviously about the consequences of the dishonesty, and act consistently when enforcing the sanctions, the violation of plagiarism rules may decrease (Babaii \& Nejadghanbar, 2017; Ersoy \& Ozden, 2011; Uzun, 2014). This issue is vital not only for the level of morality of the nations but this act also affects the level of learning directly. To illustrate, the research by McGregor and Williamson (2005) explored the difference in learning between the students who plagiarize most and who plagiarized least, and the results indicated that the students who plagiarized most were less familiar with the content, remembered less about them a month later, and had less interest, willingness and enthusiasm to learn or understand the content. Furthermore, it prevents students.

According to literature besides students, academicians also do plagiarism since "Easily availability of reading materials/text on the internet. Study Pressure on students. Disorganization of syllabus for examination. Poor study habits of students and teachers. Cut-and-Paste culture in research and academic community. Lack of understanding of seriousness of plagiarism. Lack of strict academic discipline. Lack of research methods skills. Lack of referencing/citation skills. Workload and stressful environment” (Singh, Ram, \& Satsangi, 2015, p. 230). In addition to these, literature also showed that the authors do plagiarism due to the fact that they have low writing skills, and have to publish in second language (Pecorari \& Petric, 2014).

Existing research in Turkey in the last ten years, among 15 studies, provides limited information about the extent of academicians do plagiarism. Only two studies of the sample were conducted with graduate students in Turkey. Furthermore, plagiarism is a growing problem of publishing academic work (Bakhtiyari et al., 2014), however, there have not been any studies carried out to explore the academic staff's views, knowledge level, plagiarism 
experiences yet. The existing research in the recent years, not only focusing on the student plagiarism but also the plagiarism of professors (ex. Jeffery \& Fries, 2011; Roig, 2001). Researchers are accepted as one of the most well-informed groups in academic dishonesty, however, the researchers rarely have studied on the academic dishonesty among Turkish graduate students and academicians. There were many plagiarism events faced by many authors in the country as the author of this study witnessed by being a victim in Turkey. One of the loudest events was experienced with theoretical physicians in 2007 which included 15 authors and 70 papers (Brumfiel, 2007). These papers and authors were removed from arXiv, some of them were dismissed from the universities but some of them were not. Their most popular defense was that they were just "borrowing better English" (Kaya, 2014; Yilmaz, 2007). There are many such incidents and the cases are not over for many years. In this Turkish context, it is still surprising why academicians conduct research on plagiarism of graduate students, professors, and the published journal papers. Knowing the faculty member's behaviors' significant influence on the formation of a student's values and standards (Swazey, Anderson, \& Louis, 1993), educating prospective academicians in high ethical and moral environment is very vital for the future of the academy. The unethical plagiarism behaviors give harm to both the plagiarized authors and readers in many ways; dishonoring authors, causing decrease in their work, and misleading readers (Scanlon, 2007). How these severe level of plagiarism in Turkey will affect the future behaviors of an individuals, and the degree of educational institutions academic attainments will be seen soon.

\section{References}

Amos, K. (2014). The ethics of scholarly publishing: Exploring differences in plagiarism and duplicate publication across nations. Journal of Medical Library Association, 102(2), 87-91. https://doi.org/10.3163/1536-5050.102.2.005

Arhin, A. O., \& Jones, A. A. (2009). A multidiscipline exploration of college students' perceptions of academic dishonesty: Are nursing students different from other college students? Nurse Education Today, 29(7), 710-714. https://doi.org/10.1016/j.nedt.2009.03.001

Ashworth, P., Bannister, P., \& Thorne, P. (1997). Guilty in whose eyes? University students' perceptions of cheating and plagiarism in academic work and assessment. Studies in Higher Education, 22(2), 187-203. https://doi.org/10.1080/03075079712331381034

Avarogullari, M., \& Ata, B. (2013). Social studies teacher candidates and plagiarism: Their foreknowledge, prevalence of plagiarism, and methods they use. Gaziosmanpaşa Journal of Scientific Research, 4, 94-107.

Babaii, E., \& Nejadghanbar, H. (2017). Plagiarism among Iranian graduate students of language studies:

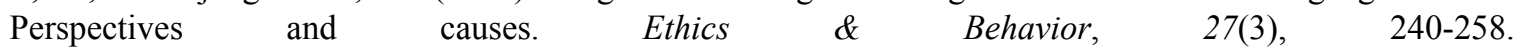
https://doi.org/10.1080/10508422.2016.1138864

Bakhtiyari, K., Salehi, H., Embi, M. A., Shakiba, M., Zavvari, A., Shahbazi-Moghadam, M., ... Mohammadjafari, M. (2014). Ethical and unethical methods of plagiarism prevention in academic writing. International Education Studies, 7(7), 52-62. https://doi.org/10.5539/ies.v7n7p52

Baty, P. (2001). Cambridge postgrad fights to clear his name. Times Higher Education Supplement, 9.

Bowden, D. (1996). Coming to terms: Plagiarism. The English Journal, 85(4), 82-84. https://doi.org/10.2307/819650

Broeckelman, M. A., \& Pollock, T. P. (2006). An honest look at academic dishonesty at Ohio University. Ohio: School of Communication Studies.

Brumfiel, G. (2007). Turkish physicists face accusations of plagiarism. Nature, 449(8). https://doi.org/10.1038/449008b

Bruton, S., \& Childers, D. (2016). The ethics and politics of policing plagiarism: A qualitative study of faculty views on student plagiarism and Turnitin. Assessment \& Evaluation in Higher Education, 41(2), 316-330. https://doi.org/10.1080/02602938.2015.1008981

Denzin, N. K. (2012). Triangulation 2.0. Journal of Mixed Method Research, 6(2), 80-88. https://doi.org/10.1177/1558689812437186

Devlin, M., \& Gray, K. (2007). In their own words: A qualitative study of the reasons Australian university student plagiarise. Higher Education Research and Development, 26(2), 181-198. https://doi.org/10.1080/07294360701310805 
Ehrich, J., Howard, S. J., Mu, C., \& Bokosmaty, S. (2016). A comparison of Chinese and Australian university students' attitudes towards plagiarism. Studies in Higher Education, 41, 231-246. https://doi.org/10.1080/03075079.2014.927850

Eret, E., \& Gökmenoğlu, T. (2010). Plagiarism in Higher Education. World Conference on Educational Sciences, Istanbul/Turkey.

Eret, E., \& Ok, A. (2014). Internet plagiarism in higher education: Tendencies, triggering factors and reasons among teacher candidates. Assessment \& Evaluation in Higher Education, 39(8), 1002-1016. https://doi.org/10.1080/02602938.2014.880776

Ersoy, A. (2014). I was not aware i plagiarized from online resources: A phenomenological research. Pamukkale University Journal of Education, 35, 47-60. https://doi.org/10.9779/PUJE654

Ersoy, A., \& Ozden, M. (2011). The views of teacher candidates regarding the role of instructor in plagiarizing from Internet in their assignments. Elementary Education Online, 10(2), 608-619.

Gibaldi, J. (1999). MLA handbook for writers of research papers (5th ed.). New York: The Modern Language Association of America.

Groom, N. (2000). The fine art of making it by faking it. Times Higher Education Supplement, 7, 18-19.

Gullifer, J. M., \& Tyson, G. A. (2014). Who has read the policy on plagiarism? Unpacking students' understanding of plagiarism. Studies in Higher Education, 39(7), 1202-1218. https://doi.org/10.1080/03075079.2013.777412

Gumusgul, O., Ustun, U. D., Isik, U., \& Demirel, D. H. (2014). Evaluation of academic dishonesty level of students studying at school of physical education and sports. Ankara Üniversitesi Spor Bil. Fak., 11(2), 131-138.

Gururajan, R., \& Roberts, D. (2005). Attitude towards plagiarism in information systems in Australian universities. Paper to be presented at the $9^{\text {th }}$ Pacific Asia Conference on Information Systems, Bangkok.

Hurriyet Daily News. (2016). Plagiarism scandal hits Turkish academia. Retrieved July 22, 2017, from http://www.hurriyetdailynews.com/plagiarism-scandal-hits-turkish-academia-.aspx?pageID=238\&nID=101 $141 \&$ NewsCatID $=341$

Janowski, A. (2002). Plagiarism: Prevention, not prosecution. Book Report, 21(2), 26-28.

Jeffery, D. D., \& Fries, J. (2011). Unauthorized uses of a coauthored work and a doctoral dissertation. Ethics \& Behavior, 21(2), 118-126. https://doi.org/10.1080/10508422.2011.551469

Kam, C. C. S., Hue, M. T., \& Cheung, H. Y. (2017). Plagiarism of Chinese secondary school students in Hong Kong. Ethics \& Behavior, O(0), 1-20. https://doi.org/10.1080/10508422.2017.1333909

Kaya, A. (2014). What the Turkish higher education system needs: A revolution. Turkish Review, 4(5), 496.

Kayaoglu, M. N., Erbay, S., Flitner, C., \& Saltas, D. (2015). Examining students' perceptions of plagiarism: A cross-cultural study at tertiary level. Journal of Further and Higher Education, 40(5), 682-705. https://doi.org/10.1080/0309877X.2015.1014320

Kocak, F., \& Ozbek, O. (2016). Views of postgraduate students regarding research ethics in Turkey. Journal of Human Sciences, 13(2), 3560-3570. https://doi.org/10.14687/jhs.v13i2.3780

Krathwohl, D. R. (1998). Methods of educational and social science research: An integrated approach (2nd ed.). Longman, New York.

Love, P. G., \& Simmons, J. (1998). Factors influencing cheating and plagiarism among graduate students in a college of education. College Student Journal, 32(4), 539-550.

Martin, B. (1986). Academic exploitation. In B. Martin, C. M. Baker, C. Manwell, \& C. Pugh (Eds.), Intellectual Suppression: Australian Case Histories, Analysis and Responses (pp. 59-62). Sydney: Angus \& Robertson.

Morgan, B., \& Thomson, A. (1997). Keele to probe standard of PhDs. Times Higher Education Supplement, 7.

Newstead, S. E., Franklyn-Stokes, A., \& Armistead, P. (1996). Individual differences in student cheating. Journal of Educational Psychology, 88(2), 229-241. https://doi.org/10.1037/0022-0663.88.2.229

Olson, K. R., \& Shaw, A. (2011). "No fair, copycat!” What children's response to plagiarism tells us about their understanding of ideas. Developmental Science, 14, 431-439. https://doi.org/10.1111/j.1467-7687.2010.00993.x 
Ozenc Ucak, N., \& Unal, Y. (2017). Farklı eğitim ve kültürlerdeki üniversite öğrencilerinin intihal ve kopyaya ilişkin görüş ve davranışları. Edebiyat Fakültesi Dergisi, 34(1).

Paldy, L. G. (1996). The problem that won't go away: Addressing the causes of cheating. Journal of College Science Teaching, 26(1), 4-6.

Papermasters. (2009). What is plagiarism? An attempt to clear the murky waters. Retrieved from http://www.papermasters.com/what-is-plagiarism.html

Park, C. (2003). In Other (People's) Words: Plagiarism by university students-Literature and lessons. Assessment and Evaluation in Higher Education, 28(5), 471-488. https://doi.org/10.1080/02602930301677

Pecorari, D., \& Petric, B. (2014). Plagiarism in second-language writing. Language Teaching, 47(3), 269-302. https://doi.org/10.1017/S0261444814000056

Plagiarism. (n.d.). In Online Etymology Dictionary. Retrieved from http://www.etymonline.com/

Price, J., \& Price, R. (2005). Finding the true incidence rate of plagiarism. International Education Journal, 6(4), 421-429.

Rakovski, C. C., \& Levy, E. S. (2007). Academic dishonesty: Perceptions of business students. College Student Journal, 41(2), 466-481.

Rocha Erkaya, O. (2009). Plagiarism by Turkish students: Causes and solutions. Asian EFL Journal, 11(2), 86-103.

Roig, M. (2001). Plagiarism and paraphrasing criteria of college and university professors. Ethics \& Behavior, 11(3), 307-323. https://doi.org/10.1207/S15327019EB1103_8

Scanlon, P. M. (2007). Song from myself: An anatomy of self-plagiarism. Plagiary: Cross-Disciplinary Studies in Plagiarism, Fabrication, and Falsification, 2(1), 1-10.

Scanlon, P. M., \& Neumann, D. R. (2002). Internet plagiarism among college students. Journal of College Student Development, 43, 374-385.

Sheard, J., Markham, S., \& Dick, M. (2003). Investigating differences in cheating behaviours of IT undergraduate and graduate students: The maturity and motivation factors. Higher Education Research Development, 22(1), 91-108. https://doi.org/10.1080/0729436032000056526

Singh, B. P., Ram, M., \& Satsangi, A. K. (2015). Plagiarism detection service: Its benefits and challenges for academicians and researchers. In P. Rai, R. K. Sharma, P. K. Jain, \& A. Singh (Eds.), Transforming dimension of upr challenges for new age libraries (pp. 227-237). New Delhi: National Law University Delhi Press.

Sisti, D. A. (2007). How do high school students justify Internet plagiarism? Ethics \& Behavior, 17(3), 215-231. https://doi.org/10.1080/10508420701519163

Stern, E. B., \& Havlicek, L. (1986). Academic misconduct: Results of faculty and undergraduate surveys. Journal of Allied Health, 15(2), 129-142.

Swazey, J. M., Anderson, M. S., \& Louis, K. S. (1993). Ethical problems in academic research. American Scientist, 81, 542-553.

Thomas, M. W. (2000). Eschewing credit: Heywood, Shakespeare and plagiarism before copyright. New Literary History, 31(2), 277-294. https://doi.org/10.1353/nlh.2000.0025

Turnitin. (2015). White paper-The Plagiarism Spectrum Instructor Insights into the 10 Types of Plagiarism.

Turnitin. (2017). The Plagiarism Spectrum: Tagging ten types of unoriginal work. Retrieved June, 2017, from http:/turnitin.com/assets/en_us/media/plagiarism_spectrum.php

Uzun, F. (2014). Ortaokul öğrencilerinin dijital aşırmacıllk durumları ve aşırmacılık nedenlerinin belirlenmesi (Unpublished Master's Thesis). Necmettin Erbakan University, Konya, Turkey.

Verco, K. L., \& Wise, M. J. (1996, July). Software for detecting suspected plagiarism: Comparing structure and attribute-counting systems. Paper to be presented at the First Australian Conference on Computer Science Education, Sydney/Australia.

Walker, J. (2010). Measuring plagiarism: Researching what students do, not what they say they do. Studies in Higher Education, 35(1), 41-59. https://doi.org/10.1080/03075070902912994

Whiteneck, P. (2002). What to do with a thought thief. Community College Week, 14(24), 4-7. 
Wilhoit, S. (1994). Helping students avoid plagiarism. College Teaching, 42. https://doi.org/10.1080/87567555.1994.9926849

Witton, R. (1973). Academics and student supervision: Apprenticeship or exploitation? Australian and New Zealand Journal of Sociology, 9(3), 71-73. https://doi.org/10.1177/144078337300900322

Wood, G. (2004). Academic original sin: Plagiarism, the internet and librarians. The Journal of Academic Librarianship, 30(3), 237-242. https://doi.org/10.1016/j.acalib.2004.02.011

Yang, F., Shaw, A., Garduno, E., \& Olson, K. R. (2014). No one likes a copycat: A cross-cultural investigation of children's response to plagiarism. Journal of Experimental Child Psychology, 121(1), 111-119. https://doi.org/10.1016/j.jecp.2013.11.008

Yilmaz, I. (2007). Plagiarism? No, we're just borrowing better English. Nature, 449(7163), 658. https://doi.org/10.1038/449658a

\section{Copyrights}

Copyright for this article is retained by the author(s), with first publication rights granted to the journal.

This is an open-access article distributed under the terms and conditions of the Creative Commons Attribution license (http://creativecommons.org/licenses/by/4.0/). 